\title{
D-vitamin mot kols?
}

\section{Høye doser D-vitamintilskudd kan bedre kronisk obstruktiv lungesyk- dom, men bare hos dem med uttalt D-vitaminmangel.}

Flere studier har vist at mange pasienter med uttalt kols har lave D-vitaminnivåer. I en belgisk studie ble 182 pasienter med moderat til alvorlig kols randomisert til D-vitamintil-

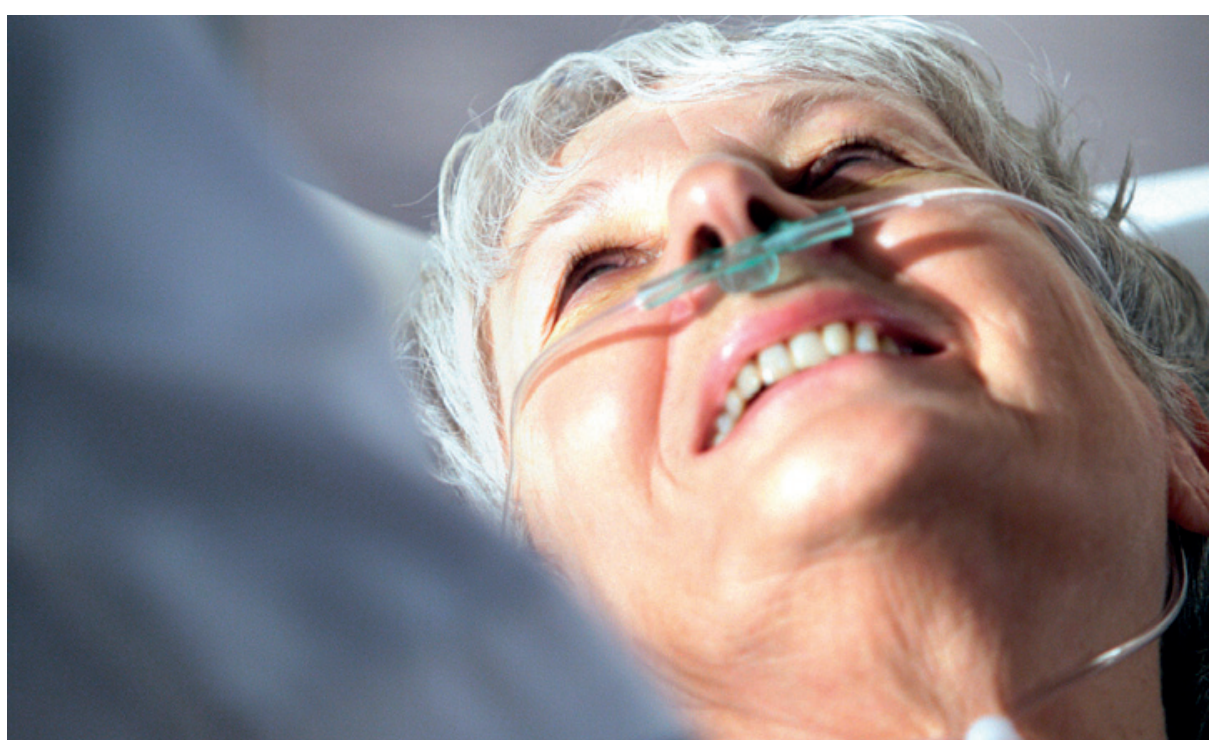

Foto Photodisc/Thinkstock skudd i høye doser eller placebo hver 4. uke i ett år (1). D-vitaminnivået steg signifikant i intervensjonsgruppen. Median tid til første eksaserbasjon av kols var tilnærmet lik i begge

grupper (hasardratio 1,$1 ; p=0,41$ ). Antall eksaserbasjoner, lungefunksjon, antall sykehusinnleggelser, livskvalitet og død var også lik. En posthocanalyse av 30 pasienter med uttalt D-vitaminmangel ved studiestart viste imidlertid signifikant færre eksaserbasjoner med D-vitamintilskudd (rateratio 0,57; $\mathrm{p}=0,042$ ).

- Denne studien tyder på at D-vitamintilskudd ikke har effekt hos de fleste pasienter med kols, sier overlege May Brit Lund ved Lungeavdelingen, Oslo universitetssykehus, Rikshospitalet. - Men studien er for liten og observasjonstiden for kort til å kunne forvente effekt på utfallsvariabler som lungefunksjon, livskvalitet og død. Kolspasienter er dessuten en heterogen gruppe med stor variasjon når det gjelder fysiologiske, immunologiske og genetiske faktorer. Subgruppeanalysen inngikk ikke i den opprinnelige studieprotokollen og omfattet svært få pasienter, så disse funnene må i særlig grad tolkes med forsiktighet, sier Lund.

\section{Petter Gjersvik}

petjense@online.no

Tidsskriftet

Litteratur

1. Lehouck A, Mathieu C, Carremans C et al. High doses of vitamin $D$ to reduce exacerbations in chronic obstructive pulmonary disease: a randomized trial. Ann Intern Med 2012; 156: 105-14.

\section{Kognitiv funksjon svekkes allerede fra 40-årene}

\section{Tverrsnittsdata alene er ikke til- strekkelig til å beregne aldersrela- terte endringer i kognitiv funksjon.}

Kognitiv funksjon avtar med alderen, men det er uklart når nedgangen inntreffer. Tverrsnittsdata av ulike fødselskohorter gjenspeiler både aldersrelasjon og tidseffekter og har derfor begrenset informasjonsverdi. Nå har en internasjonal forskergruppe utført en prospektiv kohortstudie for å undersøke kognitiv funksjon etter 45-årsalderen (1).

Rundt 5200 menn og 2200 kvinner i alderen 45-70 år ble delt inn i fem alderskategorier. I løpet av ti år ble de testet tre ganger for hukommelse, resonnement og ordforråd samt fonemisk og semantisk taleferdighet.
Bortsett fra ordforrådet, var det en nedgang i skår for alle testene i alle alderskategorier, med raskest reduksjon hos de eldste.

- Undersøkelsen føyer seg inn i diskusjonen om hvorvidt aldersrelaterte endringer $i$ kognisjon er en kontinuerlig prosess gjennom det voksne livsløp, sier professor Ivar Reinvang ved Psykologisk institutt, Universitetet i Oslo. Konklusjonen om at endringene starter før 45-årsalderen er det bred enighet om. Konklusjonen støttes av nyere data fra hjerneskanning som viser fortynning av hjernebark fra ung voksen alder.

- I flere store populasjonsbaserte studier prøver man å beregne omfanget av endringene ved å kombinere tverrsnittsdata og longitudinelle data, sier Reinvang. - Forfatterne av denne studien konkluderer med at tverr- snittsundersøkelser overestimerer nedgangen i kognisjon hos kvinner. På den annen side er det vist at longitudinelle undersøkelser underestimerer nedgangen, så et balansert mål gir det beste estimatet. Mer differensierte kognitive mål tyder på at en reduksjon i kognitivt tempo skjer kontinuerlig fra tidlig voksen alder, mens reduksjon i hukommelse og læring kommer noe senere, sier Reinvang.

\section{Trine B. Haugen}

trine.b.haugen@hioa.no

Tidsskriftet

\section{Litteratur}

1. Singh-Manoux A, Kivimaki M, Glymour MM et al. Timing of onset of cognitive decline: results from Whitehall II prospective cohort study. BMJ 2012; 344: d7622. 